\title{
Nandrolone decanoate inhibits gluconeogenesis and decreases fasting glucose in Wistar male rats
}

\author{
Stephan Pinheiro Frankenfeld', Leonardo Pires de Oliveira ${ }^{3}$, Daniele Leão Ignacio ${ }^{3}$, \\ Raquel Guimarães Coelho ${ }^{2}$, Mariana Nigro Mattos ${ }^{4}$, Andrea Claudia Freitas Ferreira ${ }^{2}$, \\ Denise Pires Carvalho ${ }^{2}$ and Rodrigo Soares Fortunato ${ }^{1}$
}

${ }^{1}$ Laboratory of Molecular Radiobiology, Institute of Biophysics Carlos Chagas Filho, UFRJ, CCS, ${ }^{2}$ Laboratory of Endocrine Physiology, Institute of Biophysics Carlos Chagas Filho, ${ }^{3}$ Laboratory of Exercise Biology, School of Physical Education and Sports and ${ }^{4}$ Laboratory of Bioenergetics, Institute of Medical Biochemistry, Federal University of Rio de Janeiro, Avenida Carlos Chagas Filho, 373, Block G - Underground - Room G0-031, 21941-902 Rio de Janeiro, RJ, Brazil

\begin{abstract}
The use of anabolic-androgenic steroids to improve physical performance or appearance has increased notably. The doses used are 10- to 100- fold higher than the therapeutic dose (TD), and this abuse can cause several side effects. Glucose metabolism is significantly affected by anabolic-androgenic steroid abuse, but studies about glycemic regulation during fasting are scarce. There are some evidences showing that testosterone can antagonize glucocorticoids action, which are crucial to glucose production during fasting. Thus, the aim of this study was to determine the impact of supraphysiological doses (SDs) of nandrolone decanoate (DECA) on rat glucose metabolism during fasting. Male Wistar rats were treated with i.m. injections of vehicle, a low TD $(0.016 \mathrm{mg} / 100 \mathrm{~g}$ b.w.-TD group) or a high SD $(1 \mathrm{mg} / 100 \mathrm{~g}$ b.w.-SD group) of DECA, once a week for 8 weeks. After $12 \mathrm{~h}$ fasting, we evaluated glucose and pyruvate tolerance tests, liver glycogen content, serum levels of gluconeogenic substrates, insulin and corticosterone, glucose uptake and hexokinase (HK) activity in skeletal muscle, and the adrenal catecholamine content. SD group had increased serum insulin levels and a blunted response to insulin regarding glucose uptake in skeletal muscle. Fasting serum glucose decreased significantly in SD group, as well as the pyruvate tolerance test and liver glycogen content. Moreover, serum levels of glycerol were increased in SD group. Our data indicate that SDs of DECA exert effects on different regulatory points of glucose metabolism, resulting in defective gluconeogenesis and decreased skeletal muscle glucose uptake in response to insulin.
\end{abstract}

Journal of Endocrinology (2014) 220, 143-153

Correspondence should be addressed to R S Fortunato Email rodrigof@biof.ufrj.br
Key Words
- glucose
- anabolic-androgenic steroids
- gluconeogenesis
- insulin

\section{Introduction}

Anabolic-androgenic steroids are synthetic molecules similar to the male sex hormone testosterone. These substances are classically used for the treatment of hypogonadism, bone marrow failure syndromes, bone mineralization, and some muscle-wasting disorders
(Shahidi 2001). However, the use of anabolic-androgenic steroids to improve physical performance has notably increased, and doses up to 10- to 100-fold higher than the therapeutic dose (TD) are being used, and this abuse can cause several adverse effects (Yesalis \& Bahrke 1995). 
The most documented side effects of anabolicandrogenic steroids abuse are those on liver, including structural and functional alterations such as cholestatic jaundice, peliosis hepatitis, hepatocellular hyperplasia, and hepatocellular adenoma (Shoupe \& Lobo 1984). In addition, other alterations are frequently documented, such as decreased HDL and increased LDL, which are involved in atherosclerosis and peripheral vascular disease. A reduction in endogenous testosterone levels, gonadotropic hormones, sex hormone-binding globulin, testis weight, sperm count, and sperm motility was also described (Shahidi 2001, Casavant et al. 2007).

Although there are some studies of testosterone effects on glucose metabolism, the effects of supraphysiological doses (SDs) of anabolic-androgenic steroids on glucose metabolism are scarce. It is well-known that women with polycystic ovarian syndrome, who have hyperandrogenism, might present hyperinsulinemia with relatively mild glucose intolerance (Chang et al. 1983). Intriguingly, in men, low testosterone serum concentration is associated with increased risk of diabetes mellitus (Haffner et al. 1996, Defay et al. 1998). Previous studies have demonstrated that the administration of nandrolone, but not testosterone, for contraception enhanced insulin-independent glucose uptake in men (Hobbs et al. 1996). Also, castrated male rats have decreased rates of glucose disposal, which is normalized by the administration of low doses of testosterone. On the other hand, animals treated with high doses of testosterone have decreased glucose disposal rates (Hollmang \& Bjorntorp 1992). Bodybuilders, who self-administer SDs of anabolic-androgenic steroids, have diminished glucose tolerance and increased insulin resistance (Shoupe \& Lobo 1984, Cohen \& Hickman 1987). However, some studies report normal glucose metabolism when high anabolic-androgenic steroids doses are used in rats. Thus, the effect of high doses of anabolic-androgenic steroids on glucose metabolism remains controversial (Hislop et al. 1999, Takahashi et al. 2004).

Previous studies about the side effects of anabolicandrogenic steroids abuse on glycemic control are controversial, and the majority of them were focused on insulin levels and/or resistance. Glucose production during fasting is crucial to maintain glycemia within physiological ranges, and is regulated by several hormones, such as glucagon, catecholamines, and glucocorticoids (Cryer 2011). There are some evidences showing that androgens can antagonize glucocorticoids effects through binding to glucocorticoid receptor or decreasing its expression (Hickson et al. 1990), thus, we hypothesized that SDs of anabolic-androgenic steroids could interfere in fasting glycemic control. Therefore, our purpose in this study was to investigate the effects of chronic treatment with SDs of nandrolone decanoate on glucose metabolism during fasting.

\section{Materials and methods}

\section{Experimental group}

Three-month-old male Wistar rats weighing 200-250 g were maintained in an animal house with controlled lightening (12 h light:12 h darkness cycle) and temperature $\left(23-24^{\circ} \mathrm{C}\right.$ ). The Institutional Committee for Use of Animals in Research approved the study, and the procedures were in compliance with the International Guiding Principles for Biomedical Research Involving Animals of the Council for International Organizations of Medical Sciences (Geneva, Switzerland). The nandrolone decanoate protocol used in this research was approved (IBCCF159), and the animals were divided into three groups: control rats (that received only vehicle injection (peanut oil with $10 \%$ of benzoic alcohol)), rats treated with $0.016 \mathrm{mg} / 100 \mathrm{~g}$ b.w. nandrolone decanoate (Deca Durabolin; Schering-Plough, São Paulo, Brazil) (TD), and rats treated with $1 \mathrm{mg} / 100 \mathrm{~g}$ b.w. nandrolone decanoate (SD). Steroid and vehicle were administered by an i.m. injection in the hind limb, once a week, for 8 weeks. TD is usually recommended for hypogonadism in humans and the SD used was 60 times higher, and corresponds to the dose generally used by anabolic steroids abusers. We have previously shown that the TD used for 8 weeks leads to decreased testicular weight and increased kidney and heart weight (Fortunato et al. 2006). One week after the last injection, the rats were killed by decapitation, and trunk blood was immediately collected. After collection, the blood was centrifuged (15 min, $3000 \boldsymbol{g}$ ) and serum was collected and stored at $-20{ }^{\circ} \mathrm{C}$. Retroperitoneal and epididymal adipose tissues were dissected out and weighed. Liver sample was obtained for liver glycogen content analysis, tibialis anterior muscle was excised for determination of glucose uptake and HK activity, and adrenal glands were used for catecholamines determination.

\section{Body composition analysis}

Body composition was determined by carcass analysis, as previously reported (Leshner \& Litwin 1972). After killing, the animals were eviscerated, and the carcass without retroperitoneal and visceral fat was weighed, autoclaved for $1 \mathrm{~h}$, and homogenized in distilled water $(1: 1 \mathrm{w} / \mathrm{v})$. The homogenate was stored at $-20^{\circ} \mathrm{C}$ for later analysis.

Published by Bioscientifica Ltd. 
Three grams of homogenate were used to determine its fat content gravimetrically. The samples were hydrolyzed in a shaking water bath at $70{ }^{\circ} \mathrm{C}$ for $2 \mathrm{~h}$ with $30 \% \mathrm{KOH}$ and ethanol. Total fatty acids and free cholesterol were extracted by three successive extractions with petroleum ether. After overnight drying, all tubes were weighed, and the result was expressed as grams of fat per $100 \mathrm{~g}$ carcass. Protein content was determined in $1 \mathrm{~g}$ of homogenate. The tubes were centrifuged at $2000 \boldsymbol{g}$ for $10 \mathrm{~min}$. Total protein concentrations were determined by Lowry method (Lowry et al. 1951). Results were expressed as gram of protein per $100 \mathrm{~g}$ carcasses. Water content was determined by the dehydration of $3 \mathrm{~g}$ of samples at $70^{\circ} \mathrm{C}$. The result was given as the difference between the initial sample weight and the final weight and was expressed as gram of water per $100 \mathrm{~g}$ carcass.

\section{Liver glycogen content}

Liver glycogen was measured as previously described (Casimiro-Lopes et al. 2008). Liver was homogenized in $10 \%$ TCA (w/v) followed by centrifugation at $1000 \mathrm{~g}$ and $4{ }^{\circ} \mathrm{C}$ for $10 \mathrm{~min}$. Two mililiter of supernatant were added to $5 \mathrm{ml}$ of absolute ethanol and incubated overnight at $20^{\circ} \mathrm{C}$. The samples were, then, centrifuged at $1000 \mathrm{~g}$ and $4{ }^{\circ} \mathrm{C}$ for $10 \mathrm{~min}$, and the supernatant was discarded. The pellet was boiled for $30 \mathrm{~min}$ in $1 \mathrm{M} \mathrm{HCl}$ in order to hydrolyze precipitated glycogen. The mixture was neutralized by the addition of $1 \mathrm{ml} 1 \mathrm{M} \mathrm{NaOH}$. Glucose produced by the hydrolysis of glycogen was measured using a commercial kit (Glucox, Goiania, Brazil).

\section{Glucose and pyruvate tolerance tests}

Rats were fasted for $12 \mathrm{~h}$. After the collection of a basal blood sample (time 0), a solution of glucose ( $2 \mathrm{~g}$ glucose/kg b.w.) or pyruvate ( $\mathrm{g}$ pyruvate/kg b.w.) was administered orally by gavage (glucose tolerance test) or i.p. (pyruvate tolerance test). Blood samples were collected from the tail tip at 30, 60, 120, and $180 \mathrm{~min}$ after the administration of glucose solution to determine serum glucose concentrations. Areas under the curve over these 120 min of glucose or pyruvate tolerance tests were calculated and compared.

\section{Glucose 6-phosphatase (G6Pase) and phosphoenolpyruvate carboxykinase (PEPCK (PCK2)) expression in the liver}

Liver samples were homogenized in protein lysis buffer, containing $150 \mathrm{mM} \mathrm{NaCl}, 1 \mathrm{mM} \mathrm{MgCl}_{2}, 2.7 \mathrm{mM} \mathrm{KCl}$,
$20 \mathrm{mM}$ Tris, $\mathrm{pH}$ 8.0, 1\% Triton X-100, 10\% glycerol, $0.5 \mathrm{mM} \mathrm{NaVO}, 1 \mu \mathrm{M}$ phenylmethylsulphonyl fluoride, $10 \mathrm{mM} \mathrm{NaF}$, and protease and phosphatase inhibitor cocktails (SIGMA P8340 and SIGMA P0044 respectively) using an Ultra-Turrax T25 homogenizer (Fisher Scientific, Inc., Pittsburgh, PA, USA). After centrifugation at $1000 \mathrm{~g}$, the supernatant was collected and the protein concentration was determined by BCA assay kit (Pierce, Rockford, IL, USA), using the methodology described by the manufacturer. Protein samples were resolved on $10 \%$ polyacrylamide gels according to Laemmli (1970). Electrotransfer of proteins from the gel to PVDF membranes was performed at $110 \mathrm{~V}$ in a buffer containing $192 \mathrm{~mm}$ glycine and $20 \%$ methanol for $120 \mathrm{~min}$. The membranes were blocked with BSA 5\% in Tris-buffered saline with $0.1 \%$ Tween 20 for $1 \mathrm{~h}$ at room temperature. The membranes were then incubated with primary antibodies for glucose 6-phosphatase (G6Pase) or phosphoenolpyruvate carboxykinase (PEPCK) (sc-27198 and sc-32879 respectively, Santa Cruz Biotechnology) overnight at $4{ }^{\circ} \mathrm{C}$, washed, and incubated with secondary antibody (Sigma) for $2 \mathrm{~h}$ at room temperature. The immunocomplex was detected using an ECL kit (Millipore, Bedford, MA, USA).

\section{Glucose consumption and hexokinase activity in isolated skeletal muscle}

Intact tibialis anterior muscles were incubated in $50 \mathrm{mM}$ Tris-HCl buffer ( $\mathrm{pH}$ 7.4) containing $0.25 \mathrm{M}$ sucrose, $20 \mathrm{mM} \mathrm{KF}, 0.2 \mathrm{mM}$ 2-mercaptoethanol, and $5 \mathrm{mM}$ glucose in the presence or absence of $100 \mathrm{nM}$ insulin, as previously described (Coelho et al. 2011). In brief, after $90 \mathrm{~min}$ of incubation, glucose uptake was evaluated by the difference in the glucose content in the incubation medium. Glucose content was evaluated using a commercial kit (Doles, Goiania, Brazil). After the incubation period, the muscles were homogenized in the same buffer to measure hexokinase (HK) activity. HK activity was measured in a medium containing $50 \mathrm{mM}$ Tris- $\mathrm{HCl}(\mathrm{pH}$ 7.4), $5 \mathrm{mM}$ $\mathrm{MgCl}_{2}, 1 \mathrm{mM}$ glucose, $1 \mathrm{mM}$ ATP, $0.2 \mathrm{mM}$ NADP, and $1 \mathrm{U} / \mathrm{ml}$ glucose 6-phosphate dehydrogenase, as previously described (Leite et al. 2011). For enzymatic analysis, NADP reduction was determined by the change in absorbance at $340 \mathrm{~nm}$ in a microplate reader (Victor X4, PerkinElmer, Norwalk, CT). Reactions were initiated by the addition of an aliquot of the homogenate and were followed during the first-order kinetics period. Blanks containing no enzymes were used to control for nonspecific NADP reduction. The results were expressed as \% of control

Published by Bioscientifica Ltd. 
(without insulin) for glucose consumption, and in nmol $\mathrm{NADP} / \mathrm{mg}$ per min for HK activity.

\section{Hormonal measurements}

Total serum insulin and corticosterone were determined by specific Coated-Tube RIA kits (Insulin: Coat-A-Count, EUA, sensitivity: $4.2 \mu \mathrm{IU} / \mathrm{ml}$, intra-assay coefficient of variation: 4.3\%; corticosterone: Coat-A-Count, EUA, sensitivity: $50 \mathrm{ng} / \mathrm{ml}$, intra-assay coefficient of variation: $4.4 \%)$. Serum testosterone levels were measured using eletrochemiluminescence commercial kit (Roche Diagnosticas, sensitivity: $2.5 \mathrm{ng} / \mathrm{dl}$, intra-assay coefficient of variation: $4.0 \%)$. All procedures were carried out following the fabricant recommendations.

The total levels of catecholamines (adrenaline and noradrenaline) were quantified using the trihydroxyindole method (Kelner et al. 1985). Adrenal glands were homogenized in $10 \%$ acetic acid and centrifuged $(1120 \mathrm{~g}, 5 \mathrm{~min})$. The supernatants were kept frozen for later analysis. Briefly, $50 \mu \mathrm{l}$ of the standard or supernatant were mixed with $250 \mu \mathrm{l} 0.5 \mathrm{M}$ phosphate buffer, $\mathrm{pH} 7.0$ and $25 \mu \mathrm{l} 0.5 \%$ potassium ferricyanate, followed by incubation (20 min; ice bath). The reaction was stopped with $500 \mu \mathrm{l}$ of $60 \mathrm{mg} / \mathrm{ml}$ ascorbic acid/5 $\mathrm{M} \mathrm{NaOH}$ (1:19 proportion), and the samples were diluted with $2 \mathrm{ml}$ of water. Adrenaline standards were used for quantification. The parameters used in the fluorometer (Victor X4, PerkinElmer) were $420 \mathrm{~nm}$ excitation and $510 \mathrm{~nm}$ emission.

\section{Serum glycerol, lactate, and amino acids concentrations}

Serum glycerol concentration was determined using the Free Glycerol Reagent (Sigma), following the fabricant recommendations.

For serum lactate analysis, $24 \mathrm{~h}$ before killing blood samples $(25 \mu \mathrm{l})$ were collected from the tail tip into tubes containing $50 \mu \mathrm{l}$ sodium fluoride $(1 \%)$, frozen $\left(-20^{\circ} \mathrm{C}\right)$, and subsequently analyzed. Concentrations were determined by an electrochemical method in a lactate analyzer (YSL 1500 STATS; Yellow Springs Instruments, Ohio, USA), which uses a membrane sensor containing immobilized L-lactate oxidase that is placed between two membrane layers of polycarbonate and cellulose acetate. In this instrument, hydrogen peroxide is produced and oxidized on a platinum electrode resulting in electrical current proportional to the concentration of lactate in the sample of whole blood.

Serum alanine concentration was evaluated as previously described (Kutlán et al. 2002). Before analysis,
$100 \mu \mathrm{l}$ of $5 \%$ perchloric acid were added to $100 \mu \mathrm{l}$ of sample, and the mixture was centrifuged at $10000 \mathrm{~g}$ for $10 \mathrm{~min}$ at $4{ }^{\circ} \mathrm{C}$. The supernatant was analyzed in an RP-HPLC system (ZORBAX AAA, Agilent, Santa Clara, CA, USA) coupled to an u.v. detector. The column $(4.6 \times 7.5 \mathrm{~mm}, 35 \mu \mathrm{M})$ temperature was $46^{\circ} \mathrm{C}$ and the flow rate was $0.6 \mathrm{ml} / \mathrm{min}$. Effluent absorbance was followed at $254 \mathrm{~nm}$.

\section{Physical capacity}

All rats were subjected to a maximum exercise test on treadmills (LSI Letica Panlab, Spain). The animals were adapted to the treadmill for 2-3 days at a speed of $10 \mathrm{~min} / \mathrm{m}$ for $5 \mathrm{~min}$. After that, the rats were subjected to a maximal speed test after a $12 \mathrm{~h}$ fast period. The test started with a speed of $10 \mathrm{~min} / \mathrm{m}$, with no inclination. Every $2 \mathrm{~min}$, the speed was increased by $1.2 \mathrm{~min} / \mathrm{m}$ and rats ran to exhaustion, characterized when they resist running though stimulated by shock. We consider a complete stage when the rat ran at least $75 \%$ of stage ( 1 and $\frac{1}{2} \mathrm{~min}$ ). Total time and final velocity were recorded, as well as the maximum speed of the $\mathrm{VO}_{2}$ max of rats, since both speed and $\mathrm{VO}_{2}$ max are related, and the maximum physical capacity of the rat can be determined by this test (Rodrigues et al. 2007).

\section{Statistical analyses}

The results are expressed as the mean \pm s.E.M. Data from body composition; serum testosterone, fasting serum glucose, and glucose tolerance test were analyzed by oneway ANOVA. The other results were analyzed by unpaired $t$-test. Statistical analyses were done using the software GraphPad Prism (version 4, GraphPad Software, Inc., San Diego, CA, USA). A value of $P \leq 0.05$ was considered statistically significant.

\section{Results}

\section{Serum testosterone levels}

Serum testosterone levels were significantly higher in SD group when compared with control and TD groups, but no differences were detected between TD and control groups (Fig. 1A).

\section{Body composition}

The SD of nandrolone decanoate (SD group) significantly decreased subcutaneous and intramuscular fat mass in

Published by Bioscientifica Ltd 


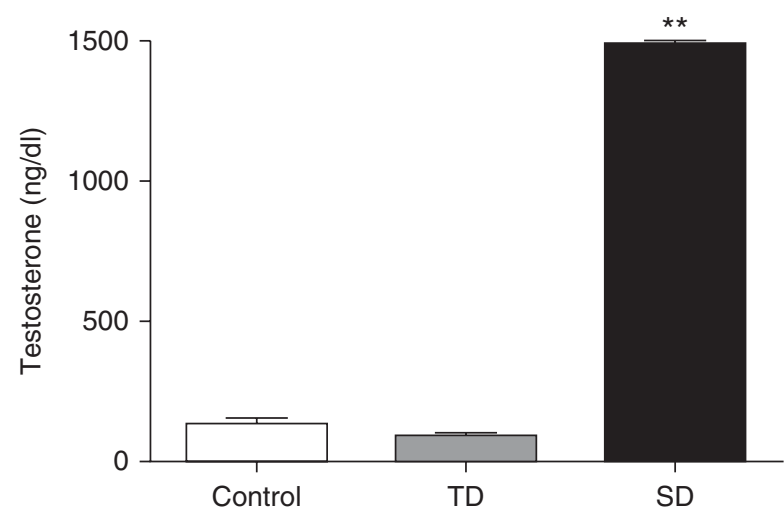

Figure 1

Serum testosterone levels of rats that received or not i.m. injections of $0.016 \mathrm{mg} / 100 \mathrm{~g}$ b.w. (TD) or $1 \mathrm{mg} / 100 \mathrm{~g}$ b.w. (SD) of Deca Durabolin (Organon), once a week for 8 weeks. Data are shown as mean \pm s.E.M. $* * P<0.001$

comparison with control and TD groups, but no changes were observed in retroperitoneal and epididymal fat mass among the groups. Body protein mass and water content were significantly higher in the SD group in comparison with control and TD groups (Table 1).

\section{Glucose tolerance test}

Fasting serum glucose was significantly lower in the SD group when compared with the control and TD groups (Fig. 2A), but no differences were detected in the glucose tolerance test (Fig. 2B and C). Once the TD of nandrolone decanoate did not alter the fasting serum glucose, the following experiments were only performed with SD and vehicle groups.

\section{Hormonal measurements}

Even though serum glucose was lower in the SD group, their serum insulin levels were significantly higher than in the controls (Fig. 3A). On the other hand, no significant differences were detected in serum corticosterone (Fig. 3B) or in the adrenal catecholamine content in the SD group (Fig. 3C).

\section{Glucose consumption and HK activity}

Muscle glucose uptake in basal conditions was similar between the groups. However, insulin incubation increased glucose uptake by $45 \%$ in the control group, while no stimulatory effect of insulin was seen in the skeletal muscle of the SD group (Fig. 4A). The HK activity did not differ between the groups (Fig. 4B). Liver glucokinase activity was lower in SD group (2.81 \pm $0.57 \mathrm{nmol} / \mathrm{mg}$ per $\min , n=10)$ in comparison with control $(5.82 \pm 0.88 \mathrm{nmol} / \mathrm{mg}$ per min, $n=10)(P<0.01)$.

\section{Pyruvate tolerance test, gluconeogenic substrates, and liver glycogen content}

Trying to elucidate the decreased fasting glycemia in the SD group, we evaluated the gluconeogenic flux through a pyruvate tolerance test. As shown in Fig. $5 \mathrm{~A}$ and B, the supraphysiological treatment with nandrolone decanoate decreased glucose synthesis from pyruvate, as shown by the smaller area under the glucose curve in the SD group, as compared with its control. The liver expression of two key gluconeogenic enzymes, G6Pase and PEPCK, was evaluated but no differences were found between them (Fig. 5C). Also, fasting liver glycogen content was significantly decreased by the SD of nandrolone decanoate (Fig. 5D).

The evaluation of the serum gluconeogenic substrates: glycerol, lactate, and alanine showed a significantly higher glycerol concentration in the SD group in comparison with its control, with no differences in the serum lactate or alanine concentrations (Table 2).

Table 1 Body composition of rats that received or not i.m. injections of $0.01 \mathrm{mg} / 100 \mathrm{~g} \mathrm{b.w.} \mathrm{(TD)} \mathrm{or} 1 \mathrm{mg} / 100 \mathrm{~g} \mathrm{b.w}$. (SD) of Deca Durabolin (Organon), once a week for 8 weeks. Data are shown as mean \pm s.E.M.

\begin{tabular}{|c|c|c|c|}
\hline & Control $(n=8)$ & TD $(n=8)$ & SD $(n=4)$ \\
\hline $\begin{array}{l}\text { Subcutaneous and intramuscular fat mass } \\
\text { ( } \mathrm{g} / 100 \mathrm{~g} \text { carcass) }\end{array}$ & $2.82 \pm 0.18$ & $2.73 \pm 0.3$ & $2.33 \pm 0.13$ \\
\hline Retroperitoneal fat mass (g/100 g b.w.) & $1.74 \pm 0.18$ & $1.62 \pm 0.24$ & $1.09 \pm 0.17$ \\
\hline Periepididymal fat mass (g/100 g b.w.) & $2.29 \pm 0.18$ & $1.92 \pm 0.11$ & $2.96 \pm 0.27 *$ \\
\hline Protein mass (g/100 g carcass) & $23.81 \pm 1.19$ & $24.02 \pm 0.81$ & $27.61 \pm 0.69 *$ \\
\hline Water content ( $\mathrm{g} / 100 \mathrm{~g}$ carcass) & $40.65 \pm 0.56$ & $40.81 \pm 0.45$ & $42.92 \pm 0.78 *$ \\
\hline
\end{tabular}

$n$, total number of rats. ${ }^{*} P<0.05$ vs control and TD groups.

http://joe.endocrinology-journals.org DOI: $10.1530 / J O E-13-0259$
(C) 2014 Society for Endocrinology Printed in Great Britain 


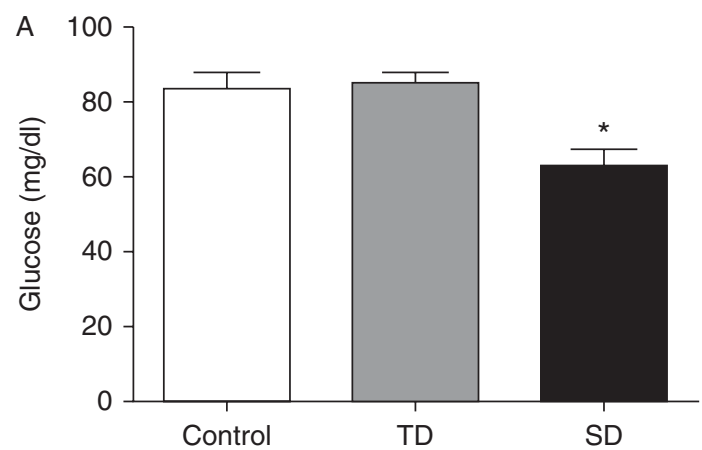

performance has increased notably (Yesalis et al. 1993). Now, these drugs have been used not only by weightlifters and elite athletes but also by bodybuilders and recreational athletes to increase their muscles and decrease fat mass (Bhasin et al. 2001). These individuals take the anabolic-androgenic steroids in a concentration 10- to 100 -fold higher than the physiological dose, and this abuse can cause a lot of side effects in the liver, reproductive and cardiovascular systems, among others
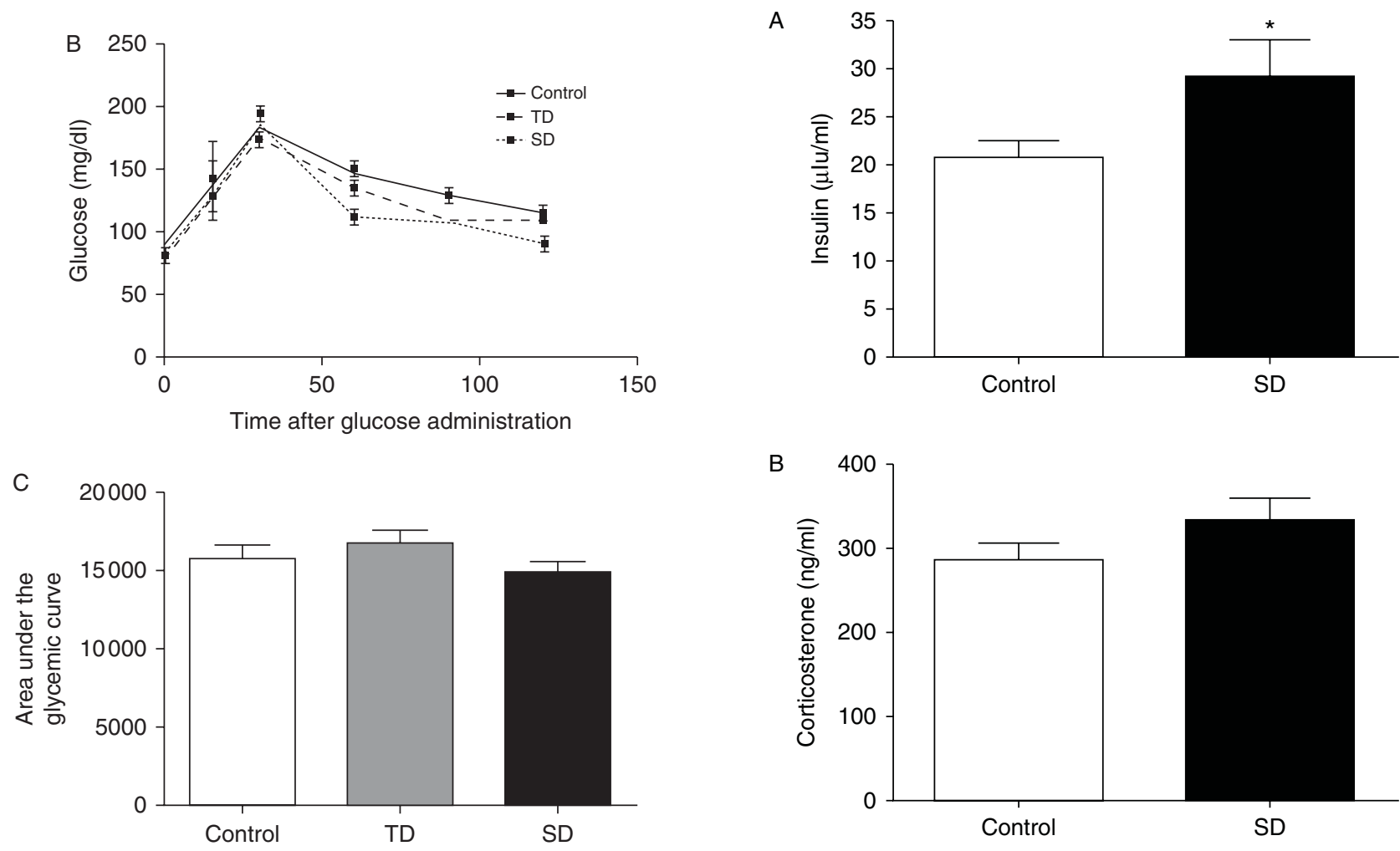

Figure 2

Fasting serum glucose (A), glucose tolerance test (B), and area under the glycemic curve (C) of rats that received or not i.m. injections of $0.016 \mathrm{mg} / 100 \mathrm{~g}$ b.w. (TD) or $1 \mathrm{mg} / 100 \mathrm{~g}$ b.w. (SD) of Deca Durabolin (Organon), once a week for about 8 weeks. Data are shown as mean \pm s.E.M. ${ }^{*} P<0.05$.

\section{Physical capacity}

The physical capacity of the animals decreased with the administration of SDs of nandrolone decanoate. As shown in Fig. $6 \mathrm{~A}$ and $\mathrm{B}$, maximum speed and total run time were lower in SD group in comparison with controls (Fig. 6A).

\section{Discussion}

The use of anabolic-androgenic steroids for changes in body composition or improvement of athletic

\begin{tabular}{|lr}
\hline http://joe.endocrinology-journals.org & ○ 2014 Society for Endocrinology \\
DOI: $10.1530 /$ JOE-13-0259 & Printed in Great Britain
\end{tabular}
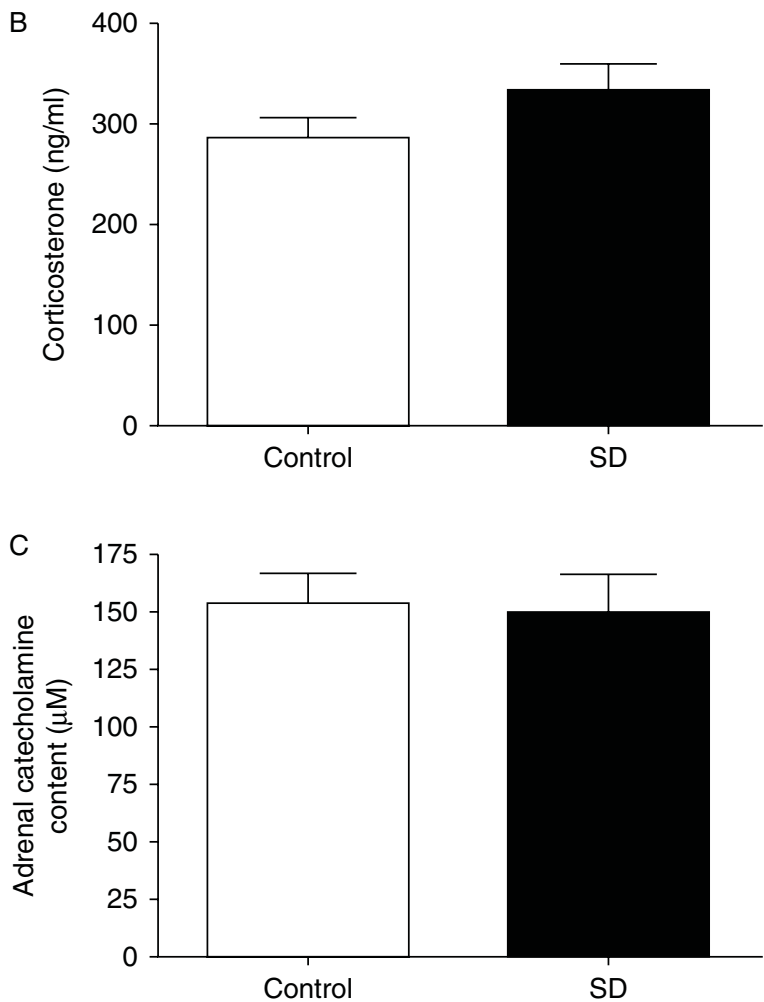

Figure 3

Serum insulin (A) and corticosterone (B) levels, and adrenal catecholamines content $(C)$ of rats that received or not i.m. injections of Deca Durabolin ( $50 \mathrm{mg} / \mathrm{ml}$ Organon, $1 \mathrm{mg} / 100 \mathrm{~g}$ b.w.), once a week for about 8 weeks. Data are shown as mean + s.E.M. $* P<0.05$. 
A
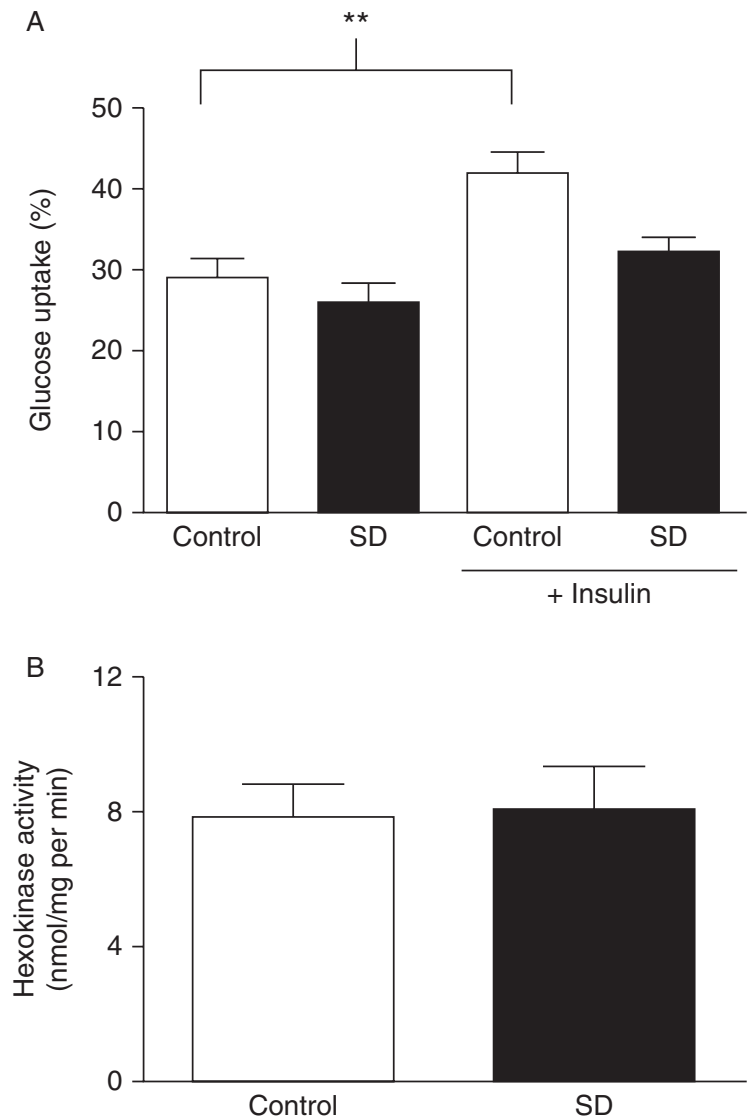

Figure 4

Glucose uptake (A) and hexokinase activity (B) in isolated skeletal muscle of rats that received or not i.m. injections of Deca Durabolin $(50 \mathrm{mg} / \mathrm{ml}$ Organon, $1 \mathrm{mg} / 100 \mathrm{~g}$ b.w.), once a week for 8 weeks. Data are shown as mean \pm S.E.M. ${ }^{*} P P<0.001$.

(Shahidi 2001, Casavant et al. 2007). In this report, we chose nandrolone decanoate, the anabolic-androgenic steroid mostly used by bodybuilders and recreational athletes, to elucidate the effects of high dosage of anabolic-androgenic steroids on glucose metabolism (Evans 1997). The choice of rats as model, and nandrolone decanoate as the only drug treatment, helped us to assess the specific actions of this drug without the interferences that can occur in studies with human subjects.

The supraphysiological DECA administration led to a significant decrease in fat mass and an increase in protein mass and water content. The lipolytic effect of testosterone is well described, and it depends on the dose administered (Böttger et al. 1970). Retroperitoneal and periepididymal fat mass were not changed by nandrolone decanoate administration, on the other hand, subcutaneous and/or intramuscular fat were decreased; thus, our data suggest that nandrolone decanoate has different
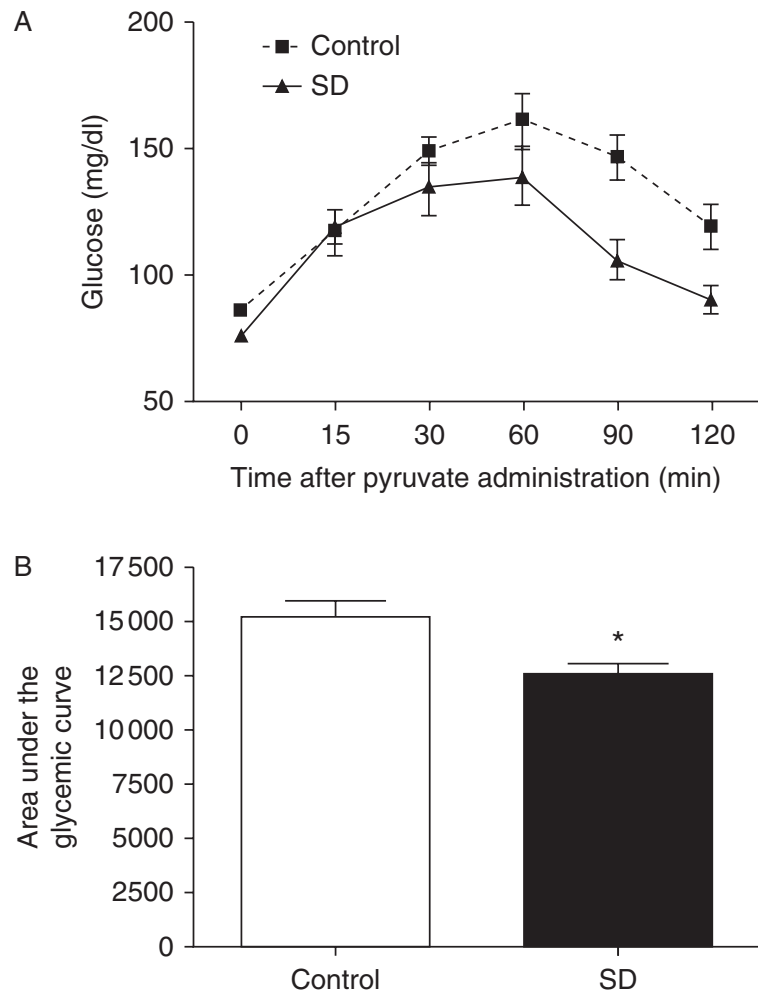

C
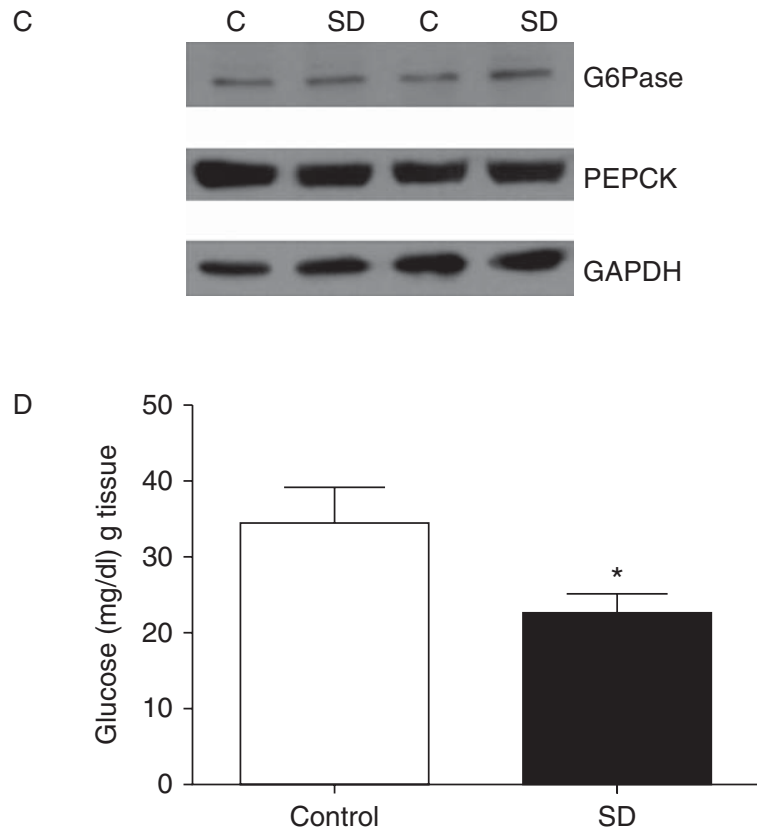

Figure 5

Pyruvate tolerance test (A), area under the glycemic curve (B), G6Pase and PEPCK protein expression (C), and liver glycogen content (D) of rats that received or not i.m. injections of Deca Durabolin $(50 \mathrm{mg} / \mathrm{ml}$ Organon, $1 \mathrm{mg} / 100 \mathrm{~g}$ b.w.), once a week for 8 weeks. Data are shown as mean \pm s.E.M. $* P<0.05$.

Published by Bioscientifica Ltd. 
Table 2 Serum concentrations of gluconeogenic substrates of rats that received or not i.m. injections of $1 \mathrm{mg} / 100 \mathrm{~g}$ b.w. (SD) of Deca Durabolin (Organon), once a week for 8 weeks. In all experiments $(n=10)$ data are shown as mean \pm S.E.M.

\begin{tabular}{|c|c|c|}
\hline & Control & Treated \\
\hline Glycerol (mg/dl) & $0.69 \pm 0.06$ & $1.72 \pm 0.32 *$ \\
\hline Lactate (mmol/l) & $0.47 \pm 0.04$ & $0.42 \pm 0.02$ \\
\hline Alanine $(\mathrm{mmol} / \mathrm{l})$ & $475.3 \pm 43.9$ & $355.7 \pm 29.2$ \\
\hline
\end{tabular}

$n$, total number of rats. ${ }^{\star} P<0.01$.

actions depending on the fat compartment analyzed. These results are in agreement with a study in which men who received different testosterone doses for 20 weeks showed a significant reduction in intramuscular adipose tissue, while the intra-abdominal adipose tissue store remained unchanged (Woodhouse et al. 2004).

Data on changes in fat-free mass by anabolicandrogenic steroids use are conflicting. The carcass method is a good tool to investigate fat-free mass, because we can specifically measure the protein content, and thus fluid retention does not interfere in the results. We found that supraphysiological DECA-treated group had significantly higher body protein and water content in comparison with the control and TD group. The increased protein mass can be explained by the anabolic-androgenic steroids effects on amino acid uptake and protein synthesis (Tamaki et al. 2001). Sinha-Hikim et al. (2006) showed an increase in $\left[{ }^{14} \mathrm{C}\right]$ leucine uptake in both dorsiflexor and plantarflexor muscles in resting anabolicandrogenic steroids-treated rats, indicating an increase in protein synthesis. In another study, older men treated with different doses of testosterone showed a dosedependent increase in cross-sectional area of type-I-and type-II muscle fibers, as well as an increase in the number of satellite cells. The increase in water content could be explained by the increase in protein mass, resulting in enhanced muscle mass and consequently in greater water content. However, we could not discriminate between extracellular or intracellular water, and the specific mechanism underlying the increased water content remains to be clarified.

There are few studies about the influence of SDs of anabolic-androgenic steroids on glucose metabolism, and the results are conflicting. Cohen \& Hickman (1987) studied on powerlifters who self-administered large doses of anabolic-androgenic steroids for a period of up to 7 years and showed that these individuals had diminished glucose tolerance in comparison with a group that has never taken these steroids. In another study, healthy young men were submitted to a suppression of endogenous testosterone production by a GNRH antagonist and then were treated with testosterone doses, ranging from 25 to $600 \mathrm{mg}$ weekly for 20 weeks. Their insulin sensitivity was evaluated and no difference was seen between the groups (Singh et al. 2002). In this study, we did not find any difference between treated and control rats in the glucose tolerance tests. However, we found a blunted response to insulin of skeletal muscle glucose uptake in the SD group, suggesting specific insulin resistance in this tissue. After glucose ingestion approximately one-third of glucose is taken up by the liver, the remainder is distributed to the other tissues, but the glucose uptake by skeletal muscle is the most important among them (Cryer 2011). Thus, it seems that the higher protein mass and serum insulin levels found in animals treated with SDs of nandrolone decanoate could counteract the insulin resistance.

Fasting serum insulin levels were higher in anabolicandrogenic steroids-treated rats in comparison with controls. The same was observed in the study of
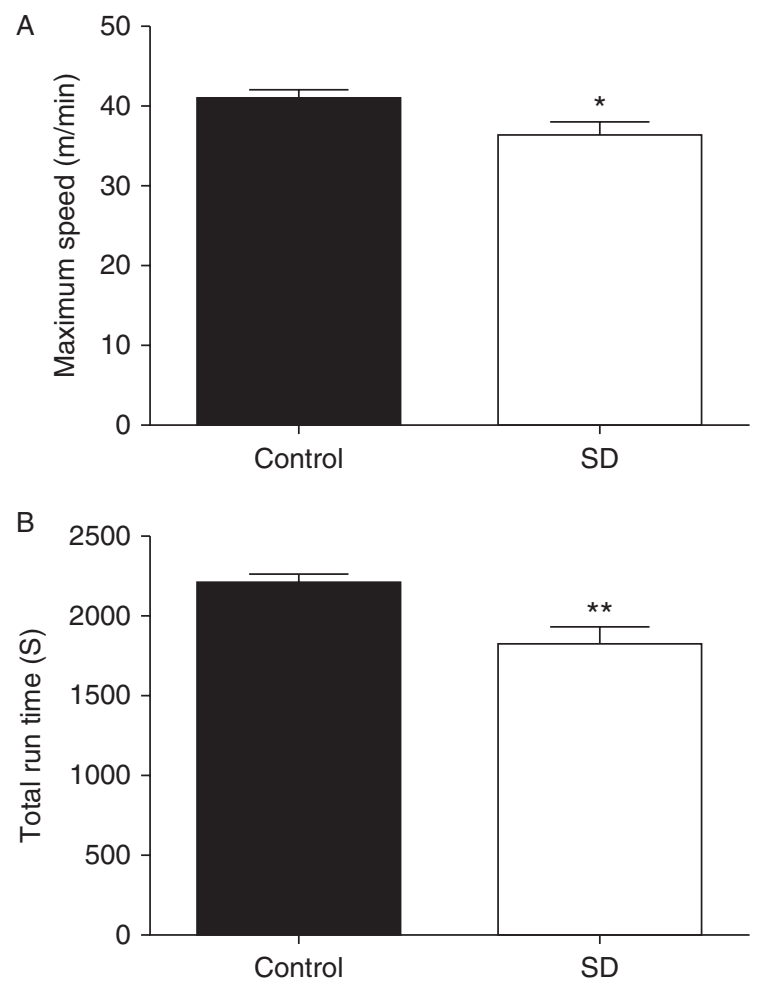

Figure 6

Maximum speed $(A)$ and total run time $(B)$ of rats that received or not i.m. injections of Deca Durabolin (1 mg/100 g b.w.), once a week for 8 weeks. Data are shown as mean \pm s.E.M. ${ }^{*} P<0.05, * * P<0.01$.

Published by Bioscientifica Ltd. 
Cohen \& Hickman (1987), in which anabolic-androgenic steroids abusers were shown to have higher fasting serum insulin concentrations when compared with non steroidusing powerlifters. Insulin secretion by $\beta$-pancreatic cells is primarily stimulated by glucose; however, serum glucose is decreased in the DECA-treated group, thus we might postulate a direct action of the anabolic-androgenic steroids on $\beta$-pancreatic cells, stimulating insulin secretion. In accordance with our hypothesis, Morimoto et al. (2001) showed that a testosterone treatment of pancreatic islets primary culture was able to increase the insulin gene promoter activity, as well as its mRNA and protein levels, demonstrating a direct stimulatory effect of testosterone upon pancreatic $\beta$-cells.

During fasting, some reactions take place to maintain glycemia in the physiological range. Liver can export glucose to the blood using glycogenolytic and gluconeogenic pathways that are, respectively, the breakdown of glycogen and the de novo formation of glucose from glycerol, lactate, or some amino acids (Cryer 2011). In this study, we showed that the fasting serum glucose was lower in the SD group than in the control and TD groups, which could be due to defective glycogenolysis, decreased gluconeogenesis, or both. In fact, in the pyruvate test, animals treated with SDs of DECA had a lower area under the serum glucose curve, characterizing a defective gluconeogenesis. Besides, we have found that serum glycerol, an important substrate for gluconeogenesis, was higher in treated animals, reflecting an increased triglyceride breakdown in adipose tissue and/or decreased utilization of glycerol for gluconeogenesis. On the other hand, liver glycogen content was lower in the treated group when compared with their control, which could reflect higher glycogen utilization due to impaired gluconeogenesis and/or defective glycogen synthesis. In fact, the decreased liver glycogen content associated with higher serum insulin levels found in rats treated with SDs of DECA suggests a resistance to the action of this hormone in the liver, as we found in skeletal muscle. Besides, SD group has lower liver glucokinase activity when compared with control group, again indicating liver insulin resistance.

Some authors have shown that gonadal hormones, such as testosterone and estradiol, can antagonize corticosterone action through inhibition of corticosteronereceptor complex formation in vitro, moreover high-affinity binding sites for gonadal hormones have been demonstrated, reinforcing this results (Agarwal \& Coupry 1977). However, no differences were found in glucose 6-phosphatase and PEPCK protein expression, two enzymes that are positively modulated by corticosterone at the transcriptional level. Furthermore, we cannot exclude a direct action of the anabolic-androgenic steroids inhibiting the activity of the gluconeogenic enzymes, as they can also be regulated post transcriptionally.

It is well documented that thyroid hormones $\left(\mathrm{T}_{3}\right.$ and $\mathrm{T}_{4}$ ) can influence the gluconeogenesis flux, increasing the activity of gluconeogenic enzymes and the transport of glycerol 3-phosphate (formed by glycerol oxidation) to the mitochondrial electron transport chain (Böttger et al. 1970, Okajima \& Ui 1979, Comte et al. 1990). We have previously reported a decrease in total $\mathrm{T}_{3}$ and free $\mathrm{T}_{4}$ in DECA-treated rats, utilizing the same protocol used in this study (Fortunato et al. 2006). Thus, the decrease in gluconeogenesis could also be, at least in part, due to a decrease in the thyroid hormone effect.

In conclusion, we report herein that high nandrolone decanoate doses lead to decreased serum glucose, accompanied by high serum insulin levels during fasting. We have shown for the first time that glucose production rate and liver glycogen content are decreased by the chronic administration of nandrolone decanoate, probably resulting in decreased fasting glucose. It is tempting to speculate that the impaired glucose production rate might correspond to the central underlying mechanism related to fasting hypoglycemia induced by nandrolone dacanoate usage, because skeletal muscle glucose uptake and liver glucokinase activity are decreased, indicating less peripheral glucose consumption due to insulin resistance. Acute hypoglycemia can induce a prothrombotic milieu and a rise in cytokines, vasoconstrictors, inflammatory markers, interleukins, and free oxygen radicals, leading to a decrease in myocardial blood flow reserve and subsequent myocardial injury with a heightened risk of cardiac arrhythmias and sudden cardiac death, which are very common in anabolic-androgenic steroids abusers (Brown et al. 2010). On the other hand, neuronal metabolism is glucose-dependent and hypoglycemia can lead to brain damage in diabetic rats (Bree et al. 2009). As the majority of anabolic-androgenic steroids abusers are active exercisers, and this tends to decrease blood glucose, our results are extremely relevant to highlight the potential danger of the indiscriminate use of these substances in sports, and the possibility of hypoglycemic crisis during exercise in androgenic anabolic users.

\section{Declaration of interest}

The authors declare that there is no conflict of interest that could be perceived as prejudicing the impartiality of the research reported.

Published by Bioscientifica Ltd. 


\section{Funding}

This research was supported by a grant from the Fundação de Amparo a Pesquisa do Rio de Janeiro (FAPERJ).

\section{Author contribution statement}

S P F designed the study, collected the data, researched the data, and wrote the article. L PO, D LI, R G C and M N M collected the data, contributed to the discussion, and reviewed and revised the manuscript. A C F F and D P C contributed to the discussion and reviewed and revised the manuscript. R S F designed the study, researched the data, and wrote the article.

\section{References}

Agarwal MK \& Coupry F 1977 Antigluconeogenic activity of gonadal steroid analogues in relation to liver glucocorticoid-receptor binding. FEBS Letters 2 172-174. (doi:10.1016/0014-5793(77)80577-2)

Bhasin S, Woodhouse LJ, Casaburi R, Singh AB, Bhasin D, Berman N, Chen X, Yarasheski KE, Magliano L, Dzekov C et al. 2001 Testosterone dose-response relationship in healthy young men. American Journal of Physiology. Endocrinology and Metabolism 281 E1172-E1181.

Böttger I, Kriegel H \& Wieland O 1970 Fluctuation of hepatic enzymes important in glucose metabolism in relation to thyroid function. European Journal of Biochemistry 13 253-257. (doi:10.1111/j.1432-1033. 1970.tb00925.x)

Bree AJ, Puente EC, Daphna-Iken D \& Fisher SJ 2009 Diabetes increases brain damage caused by 354 severe hypoglycemia. American Journal of Physiology. Endocrinology and Metabolism 297 E194-E201. (doi:10.1152/ ajpendo.91041.2008)

Brown A, Reynolds LR \& Bruemmer D 2010 Intensive glycemic control and cardiovascular disease: an update. Nature Reviews. Cardiology 7 369-375. (doi:10.1038/nrcardio.2010.35)

Casavant MJ, Blake K, Griffith J, Yates A \& Copley LM 2007 Consequences of use of anabolic androgenic steroids. Pediatric Clinics of North America 54 677-690. (doi:10.1016/j.pcl.2007.04.001)

Casimiro-Lopes G, Alves SB, Salerno VP, Passos MC, Lisboa PC \& Moura EG 2008 Maximum acute exercise tolerance in hyperthyroid and hypothyroid rats subjected to forced swimming. Hormone and Metabolic Research 40 276-280. (doi:10.1055/s-2008-1046799)

Chang RJ, Nakamura RM, Judd HL \& Kaplan SA 1983 Insulin resistance in nonobese patients with polycystic ovarian disease. Journal of Clinical Endocrinology and Metabolism 57 356-359. (doi:10.1210/jcem-57-2-356)

Coelho RG, Calaça IC, Celestrini DM, Correia AH, Costa MA \& Sola-Penna M 2011 Clotrimazole disrupts glycolysis in human breast cancer without affecting non-tumoral tissues. Molecular Genetics and Metabolism 103 394-398. (doi:10.1016/j.ymgme.2011.04.003)

Cohen JC \& Hickman R 1987 Insulin resistance and diminished glucose tolerance in powerlifters ingesting anabolic steroids. Journal of Clinical Endocrinology and Metabolism 64 960-963. (doi:10.1210/jcem-64-5-960)

Comte B, Vidal H, Laville M \& Riou JP 1990 Influence of thyroid hormones on gluconeogenesis from glycerol in rat hepatocytes: a dose-response study. Metabolism 39 259-263. (doi:10.1016/0026-0495(90)90044-D)

Cryer PE 2011 Glucose Homeostasis and Hypoglycemia. In Williams Textbook of Endocrinology, pp 1504-1505, 11th edn. Eds S Melmed, KS Polonsky, PR Larsen \& HM Kronenberg. Elsevier Saunders.

Defay R, Papoz L, Barby S, Bonnot-Lours S, Caces E \& Simon D 1998 Hormonal status and NIDDM in the European and Melanesian populations of New Caledonia: a case control study. The Caledonia Diabetes Mellitus (CALDIA) study group. International Journal of Obesity and Related Metabolic Disorders 22 927-934. (doi:10.1038/sj.ijo.0800697)

DeFronzo RA 1997 Pathogenesis of type 2 diabetes: metabolic and molecular implications for identifying diabetes genes. Diabetes Reviews 5 177-269.
Evans NA 1997 Gym and tonic: a profile of 100 male steroid users. British Journal of Sports Medicine 31 54-58. (doi:10.1136/bjsm.31.1.54)

Fortunato RS, Marassi MP, Chaves EA, Nascimento JH, Rosenthal D \& Carvalho DP 2006 Chronic administration of anabolic androgenic steroid alters murine thyroid function. Medicine and Science in Sports and Exercise 38 256-261. (doi:10.1249/01.mss.0000183357.19743.51)

Haffner SM, Shaten J, Stern MP, Smith GD \& Kuller L 1996 Low levels of sex hormone-binding globulin and testosterone predict the development of non-insulin-dependent diabetes mellitus in men. MRFIT Research Group. Multiple risk factor intervention Trial. American Journal of Epidemiology 143 889-897. (doi:10.1093/oxfordjournals.aje.a008832)

Hickson RC, Czerwinski SM, Falduto MT \& Young AP 1990 Glucocorticoid antagonism by exercise and androgenic-anabolic steroids. Medicine and Science in Sports and Exercise 22 331-340.

Hislop MS, Ratanjee BD, Soule SG \& Marais AD 1999 Effects of anabolicandrogenic steroid use or gonadal testosterone suppression on serum leptin concentration in men. European Journal of Endocrinology 141 40-46. (doi:10.1530/eje.0.1410040)

Hobbs CJ, Jones RE \& Plymate SR 1996 Nandrolone, a 19-nortestosterone, enhances insulin-independent glucose uptake in normal men. Journal of Clinical Endocrinology and Metabolism 81 1582-1585. (doi:10.1210/jc.81.4.1582)

Hollmang A \& Bjorntorp P 1992 The effects of testosterone on insulin sensitivity in male rats. Acta Physiologica Scandinavica 146 505-510. (doi:10.1111/j.1748-1716.1992.tb09452.x)

Kelner KL, Levine RA, Morita K \& Pollard HB 1985 A comparison of trihydroxyindole and HPLC/electrochemical methods for catecholamine measurement in adrenal chromaffin cells. Neurochemistry International 7 373-378. (doi:10.1016/0197-0186(85)90128-7)

Kutlán D, Presits P \& Molnár-Perl I 2002 Behavior and characteristics of amine derivatives obtained with $o$-phthaldialdehyde/3-mercaptopropionic acid and with $o$-phthaldialdehyde/ $N$-acetyl--L-cysteine reagents. Journal of Chromatography. A 949 235-248. (doi:10.1016/S0021-9673(01)01610-7)

Laemmli UK 1970 Cleavage of structural proteins during the assembly of the head of bacteriophage T4. Nature 227 680-685. (doi:10.1038/ 227680a0)

Leite TC, Coelho RG, Silva DD, Coelho WS, Marinho-Carvalho MM \& Sola-Penna M 2011 Lactate dowregulates the glycolytic enzymes hexokinase and phosphofructokinase in diverse tissues from mice. FEBS Letters 585 92-98. (doi:10.1016/j.febslet.2010.11.009)

Leshner AL \& Litwin VA 1972 A simple method for carcass analysis. Physiology \& Behavior 9 282-289. (doi:10.1016/0031-9384(72)90251-X)

Lowry OH, Rosenbrough NJ, Farr AL \& Randall RJ 1951 Protein measurement with the Folin phenol reagent. Journal of Biological Chemistry 193 265-275.

Morimoto S, Fernandez-Mejia C, Romero-Navarro G, Morales-Peza N \& Díaz-Sánchez V 2001 Testosterone effect on insulin content. Messenger ribonucleic acid levels, promoter activity, and secretion in the rat. Endocrinology 142 1442-1447. (doi:10.1210/en.142.4.1442)

Okajima F \& Ui M 1979 Metabolism of glucose in hyper- and hypo-thyroid rats in vivo. Glucose-turnover values and futile-cycle activities obtained with ${ }^{14} \mathrm{C}$ - and ${ }^{3} \mathrm{H}$-labelled glucose. Biochemical Journal 182 565-575.

Rodrigues B, Figueroa DM, Mostarda CT, Heeren MV, Irigoyen MC \& De Angelis K 2007 Maximal exercise test is a useful method for physical capacity and oxygen consumption determination in streptozotocin-diabetic rats. Cardiovascular Diabetology 13 38. (doi:10.1186/1475-2840-6-38)

Shahidi NT 2001 A review of chemistry, biological action, and clinical applications of anabolic-androgenic steroids. Clinical Therapeutics $\mathbf{2 3}$ 1355-1390. (doi:10.1016/S0149-2918(01)80114-4)

Shoupe D \& Lobo RA 1984 The influence of androgens on insulin resistance. Fertility and Sterility 41 385-388.

Singh AB, Hsia S, Alaupovic P, Sinha-Hikim I, Woodhouse L, Buchanan TA, Shen R, Bross R, Berman N \& Bhasin S 2002 The effects of varying doses of $\mathrm{T}$ on insulin sensitivity, plasma lipids, apolipoproteins, and C-reactive protein in healthy young men. Journal of Clinical Endocrinology and Metabolism 87 136-143. (doi:10.1210/jc.87.1.136) 
Sinha-Hikim I, Cornford M, Gaytan H, Lee ML \& Bhasin S 2006 Effects of testosterone supplementation on skeletal muscle fiber hypertrophy and satellite cells in community-dwelling older men. Journal of Clinical Endocrinology and Metabolism 91 3024-3033. (doi:10.1210/ jc.2006-0357)

Takahashi M, Tatsugi Y \& Kohno T 2004 Endocrinological and pathological effects of anabolic-androgenic steroid in male rats. Endocrine Journal $\mathbf{5 1}$ 425-434. (doi:10.1507/endocrj.51.425)

Tamaki T, Uchiyama S, Uchiyama Y, Akatsuka A, Roy RR \& Edgerton VR 2001 Anabolic steroids increase exercise tolerance. American Journal of Physiology. Endocrinology and Metabolism 280 E973-E981.
Woodhouse LJ, Gupta N, Bhasin M, Singh AB, Ross R, Phillips J \& Bhasin S 2004 Dose-dependent effects of testosterone on regional adipose tissue distribution in healthy young men. Journal of Clinical Endocrinology and Metabolism 89 718-726. (doi:10.1210/ jc.2003-031492)

Yesalis CE \& Bahrke MS 1995 Anabolic-androgenic steroids. Sports Medicine 19 326-340. (doi:10.2165/00007256-199519050-00003)

Yesalis CE, Kennedy NJ, Kopstein AN \& Bahrke MS 1993 Anabolicandrogenic steroid use in the United States. Journal of the American Medical Association 270 1217-1221. (doi:10.1001/jama.1993. $03510100067034)$

Received in final form 31 October 2013

Accepted 29 November 2013
Published by Bioscientifica Ltd. 